\title{
没水球体に作用する波力の特性に関する研究
}

\section{WAVE FORCES ACTING ON A SUBMERGED SPHERE UNDER REGULAR PROGRESSIVE WAVE}

\author{
岩田好一朗*・水 谷 法 美** \\ By Koichiro IWATA and Norimi MIZUTANI
}

\begin{abstract}
This paper aims to discuss the wave forces acting on a submerged sphere. Labolatory experiments were carried out to measure the wave forces and to investigate the flow conditions. The wave forces measured were decomposed into the drag and inertia forces using the Morison equation with engineering applications in mind. The maximum wave force, the applicable range of the Morison equation and the drag and inertia coefficients are mainly discussed in relation to the flow condition. The flow patterns can be classified into four types, such as the oscillating types with and without flow separation and rotating ones with and without flow separation. These flow types characterize well the wave forces. The drag and inertia coefficients, in the applicable range of the Morison equation, are given graphically as a function of the $K$. C. number, $d / h$ and $h / g T^{2}$.

Keywords : wave force, sphere, the Morison equation, force coefficients, flow visualization
\end{abstract}

\section{1. 緒言}

海岸・海洋構造物に作用する波力を正確に算定するこ とは，工学面で非常に重要な課題の 1 つである，構造物 に作用する波力に関する研究は, 従来より数多く行われ てきているが，そのほとんごが円柱を対象としたもの であり，球体に作用する波力を扱った研究は非常に少な $\left({ }^{2) \sim 7)}\right.$. 球体は, 三次元構造物の代表的な形状として考 えることができる.このため，二次元波動場に三次元物 体が置かれた場合の作用流体力の基本的な特性を明らか にすることは水理学的な見地から重要である.また，球 体は, 等方性を有する水圧に対して, 強度の面から最も 有利な形状である。このため, 海岸・海洋構造物の開発 に伴い, たとえば, 浮体構造物の係留の中間ブイ, ある いは海中備蓄タンクなどのように, 球状構造物の必要性 が考えられ，工学的な見地からもその作用波力の特性を 明らかにすることは重要な課題である.

一般に, 構造物の代表径が，入射波長に比べて十分小 さく, 波の変形が無視できる場合は, 構造物に作用する

* 正会員 工博 名古屋大学教授 （テ464-01 名古屋市千種区不老町）

** 正会員 工修 名古屋大学助手 工学部土木工学科 (同上)
波力は, Morison 式 ${ }^{8)}$ で算定されることが多い. 河野 ${ }^{2}$ は, 波動場に置かれた球体に作用する波力の特性について水 理実験を行って, 検討を加えた. その結果, 抗力係数は, Reynolds 数の増加に伴い減少する傾向があること, ま た，慣性力係数はほぼ 1.5 で与えられることを報告して いる. Jenkins and $\mathrm{Inman}^{3)}$ も同様な研究を行い, 抗力 係数が Keulegan and Carpenter 数9)の増加に伴い減少 する傾向があることを報告している．しかし，いずれの 研究も水平方向波力のみを対象としており，鉛直方向波 力の特性については議論していない. Iwata et al. ${ }^{4}$ は, 没水球体に作用する不規則波力について検討を加え，不 規則波中の波力係数は規則波中の值に比べて若干小さく なることを指摘した．しかし，慣性力が卓越する範囲の みを研究対象としており, 抗力が卓越する領域について は，論議していない。

また，いうまでもなく物体に作用する波力の特性は， 物体周りの流況の特性によって変化するため, 球体に作 用する波力を球体周りの流況の特性亡関連づけて議論す る必要がある. Jenkins and Inman ${ }^{3}$ は, 球体近傍の流 れの可視化を行い, Keulegan and Carpenter 数が 7 程 度で剝離が始まることを指摘している，しかし，球体周 りの流れは, 水深波長比, あるいは球体の設置水深など の球体周りの波動場の特性によっても大きく変化するこ 
とが考えられるため ${ }^{5)}$ ，この点についてさらに検討を加 える必要がある。

Morison 式は, 本来直立円柱に作用する波力に対し て提案された式である.このため球体に作用する波力を， Morison 式で算定できない場合のあることが著者ら ${ }^{6)}$ よって指摘されている. Morison 式が適用できなくな る原因として Proximity Effect ${ }^{10)}$ ，揚力の影響なよ゙が考 えられるが，その詳細についてはまだ十分には解明され ていないのが現状である.

本研究では，二次元波動場におかれた没水球体に作用 する波力をとりあげ，詳細な室内水理実験を行って波力 の特性を明らかにしようとするものである．本論では， まず, 球体周りの流れの特性について議論する.ついで, Morison 式の適用範囲を明らかにし, Morison 式の適 用可能な範囲の波力については，同式中の波力係数の特 性を流れの特性と関連づけながら明らかにするととも に，波力係数の定式化を行うものである.

\section{Morison 式}

球体に作用する波力ベクトル $\boldsymbol{F}$ は，揚力が無視でき ると仮定すれば, Morison 式により次式で与えられる.

$$
\boldsymbol{F}=\frac{1}{8} C_{D} \rho \pi D^{2} \boldsymbol{V}|\boldsymbol{V}|+\frac{1}{6} C_{M} \rho \pi D^{3} \dot{V}
$$

ここに, $C_{D}$ : 抗力係数, $C_{M}$ : 慣性力係数, $\boldsymbol{V}$ : 流速べ クトル, $\rho:$ 水の密度, $D$ : 球の直径, で上付ドット $(\cdot)$ は時間に関する微分を示す. 式 (1) を $x$ 方向成分, $z$ 方向成分に分離すれば， $x$ 方向波力 $F_{x}, z$ 方向波力 $F_{z}$ はそれぞれ式（2)，（3）で与えられる。なお， $x$ は， 波進行方向を正の向きとする水平軸, $z$ は, 静水面上に 原点をもち, 鉛直上向きを正の向きとする鉛直軸である.

$$
\begin{aligned}
& F_{x}=\frac{1}{8} C_{D x} \rho \pi D^{2} u \sqrt{u^{2}+w^{2}}+\frac{1}{6} C_{M x} \rho \pi D^{3} \dot{u} \\
& F_{z}=\frac{1}{8} C_{D z} \rho \pi D^{2} w \sqrt{u^{2}+w^{2}}+\frac{1}{6} C_{M z} \rho \pi D^{3} \dot{w}
\end{aligned}
$$

ここに, $u: x$ 方向水粒子速度, $w: z$ 方向水粒子速度で, 添字 $x, z$ は, それぞれ $x$ 方向, $z$ 方向に関する量で あることを示す。

式（1）から式（2），(3) を導く際に, $C_{D}=C_{D x}=$ $C_{D z}, C_{M}=C_{M x}=C_{M z}$ が成立するはずである. しかし実 際に球体に作用する波力には，揚力も含まれている可能 性があり，球体に作用する波力を Morison 式で表現す る以上は，揚力の影響は両式中の波力係数に含まれるこ とになる，また，その影響は， $x$ 方向と $z$ 方向では異 なることが考えられる. したがって, 球体に作用する波 力に含まれる揚力の影響を波力係数に含ませる場合は, 式（2），（3）中の波力係数をそれぞれ独立した量とし て扱う必要がある.

\section{3. 水理実験}

\section{（1）次元解析}

球体に作用する波力 $F$ は, 次に示される 9 個の物理 量によって支配されると考えられる4).

$F=\phi(D, d, h, U, T, \rho, \mu, g ; t)$

ここに, $d$ : 静水面から球の設置水深までの距離, $h$ :

静水深, $U$ : 流速の振幅, $T$ : 波の周期, $\mu$ : 水の分子 粘性係数, $g$ : 重力加速度, $t:$ 時間, である.

式（4）を無次元表示すると次式を得る.

$$
\frac{F}{\rho U^{2} D^{2}}=\phi^{\prime}\left(\frac{U T}{D}, \frac{U D}{\nu}, \frac{h}{g T^{2}}, \frac{D}{h}, \frac{d}{h} ; \frac{t}{T}\right) .
$$

ここに, $\nu(=\mu / \rho)$ は, 水の動粘性係数である.式 ( 5 ) の右辺で, 第 1 項の $U T / D$ は Keulegan and Carpenter 数（以下，K.C. 数と略記する)，第 2 項の $U D / \nu$ は Reynolds 数 (以下, $R e$ 数之略記する), 第 3 項は水深 波長比に相当する項, 第 4 項は無次元球径, 第 5 項は相 対没水深，第 6 項は無次元時間，である．ただし，波力 $F$ については, その最大值 $F_{m}$ (添字 $m$ は最大值を示す) に着目すれば， $t / T$ とは独立とみなすことができる.

球体周りの流況と波力とは密接な関係があるため, 球 体周りの流況も式( 5 )の右辺に示される無次元量によっ て支配されると考えられる。

\section{（2）実験条件および実験方法}

実験は, 名古屋大学工学部土木工学科の片面ガラス張 りの二次元鋼製水槽 (長さ $25 \mathrm{~m}$, 幅 $0.7 \mathrm{~m}$, 高さ $0.95 \mathrm{~m}$ ) で行われた。水槽の一端にはフラップ型造波装置が設置 されており，他端には反射波を極力小さくするために， 捨石, 消波ブロック, およびウレタンメッシュから構成 される消波装置が設置されている.

本研究で行った実験は, その目的によって, 大きく 2 種類の実験に分けられる. 1 つは，波力の計測を目的と した実験（実験 I ）であり，もう 1 つは，球体周りの流 況の可視化実験（実験 II）である. 実験 II では, 球体周 りの流況を水路の底面からも写真撮影するため, 先端部 に $1 / 8$ の勾配をもつ高さ $25 \mathrm{~cm}$ のステップ型水平床を 水路床に設置した．水平床の一部はアクリル製となって おり，その下側には防水型のアクリル製カメラケースが 取り付けてあり，水底からの写真撮影が可能となってい る。

実験 I の条件を次元解析に基づき表一1のように，ま た，実験 II の条件を実験 I の範囲の中から表一2 のよう に決めた。いずれの実験に対しても，実験波はすべて規 則進行波とした。

実験種目は実験 I が合計 900 ケース, 実験 II が合計 60 ケースとなった。 そのすべてのケースに対して, 水 位変動 $(\eta)$ と水深 $d$ における流速 $(u, w)$, 波力 $\left(F_{x}\right.$, 
表一1 実験 I の諸元

\begin{tabular}{l|l}
\hline $\mathrm{h}(\mathrm{cm})$ & 70.0 \\
\hline $\mathrm{h} / \mathrm{gT}^{2}$ & $0.054,0.028,0.018,0.011$ \\
\hline $\mathrm{d} / \mathrm{h}$ & $0.179,0.357,0.536,0.714,0.929$ \\
\hline $\mathrm{D} / \mathrm{h}$ & $0.091,0.036,0.014$ \\
\hline$u_{\mathrm{m}} \mathrm{T} / \mathrm{D}$ & $0.4 \sim 100$ \\
\hline$u_{\mathrm{m}} \mathrm{D} / \mathrm{v}$ & $320 \sim 21500$ \\
\hline
\end{tabular}

表一2 実験

\begin{tabular}{l|l}
\hline$h(\mathrm{~cm})$ & 45.0 \\
\hline $\mathrm{h} / \mathrm{gT}^{2}$ & $0.035,0.020,0.011$ \\
\hline $\mathrm{d} / \mathrm{h}$ & $0.222,0.356,0.711,0.889$ \\
\hline $\mathrm{D} / \mathrm{h}$ & $0.141,0.056,0.021$ \\
\hline$u_{\mathrm{m}} \mathrm{T} / \mathrm{D}$ & $1.7 \sim 56$ \\
\hline$u_{\mathrm{m}} \mathrm{D} / \nu$ & $880 \sim 16300$ \\
\hline
\end{tabular}

$\left.F_{z}\right)$ の計測を行い，さらに実験 IIについては，球体近 傍の流況の可視化も行った. なお，水位を電気容量式水 位計で，流速を電磁流速計で，波力を Cantilever 型波 力計 ${ }^{5)}$ で計測した．計測された水位，流速と波力の時間 波形は，すべて磁気テープとペン書レコーダーに記録さ れた．計測時間は，いずれの場合も約 1 分間とした。流 況の可視化方法は，コンデンスミルク㙦布法を採用し， 流況をモータードライブ付 $35 \mathrm{~mm}$ カメラ (5 コマ/秒) 2 台により側面と底面から同時に，また， $16 \mathrm{~mm}$ 高速シ ネカメラ (50 コマ/秒) とビデオカメラ (30コマ/秒) により側面から同時に，3〜4 周期にわたって撮影し， 解析に使用した。

\section{（3）解析方法}

実験で得られた水位変動, 流速, 波力の時間波形をサ ンプリングタイム 0.05 秒で離散化し, 式（5）中の無 次元量を計算した。計算に使用したデータの個数は 256 個（12.8 秒間に相当）である.このサンプリングタイ ムとデー夕数の值については, 事前の計算において, 本 実験で対象とした波に対しては，十分な精度が得られる ことが確かめられている.

$16 \mathrm{~mm}$ 高速シネカメラ, ビデオカメラによって撮影 された流況をコマ送り再生しながら解析することによ り, 球体近傍の流況の詳細を求めた。 さらに，2 方向か らの $35 \mathrm{~mm}$ 連続写真を解析し, 水槽奥行き方向の非対 称性についても検討を加えた。

Morison 式中の波力係数の特性を明らかにするため, 波力実験によって得られた実験結果を使い,式(2),(3) 中の波力係数を, 両式の右辺に流速, 加速度を代入して 得られる計算波力の時間波形が, 実測の波力の時間波形
に最もよく合うように最小二乗法) により計算した。た だし，加速度の時間波形は，流速の時間波形を FFT 法 により成分波に分離し, 各成分波に, 数值微分に相当す る線形伝達関数をかけ, 再合成することにより求めたも のを使用しだ).

\section{4. 実験結果とその考察}

\section{（1）球体近傍の流況の特性}

本実験によると，波動場におかれた没水球体周りの流 況は，まず，その運動成分により大きく 2 つのパターン に分類することが可能である. 1 つは, 振動流中におか れた球体周りの流況 ${ }^{11)}$ のうに, 水平方向の往復運動が 卓越したパターン（本論では振動パターンと称する）で, もう 1 つは, 球体近傍の水粒子の回転運動が卓越するパ ターン（回転パターンと称する）である．回転パターン は, 静止流体中を球体が回転する場合の流況 ${ }^{12)} に よ く$ 似

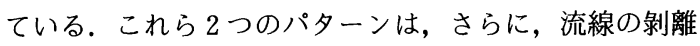

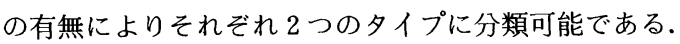
したがって, 球体周りの流況は, 合計 4 つのタイプに大 別されることになる.すなわち，(a) 振動パターンで剥 離のない振動非剥離型，(b) 振動パターンで剝離のあ る振動剝離型，(c) 回転パターンで剝離のない回転非剝 離型，および，(d) 回転パターンで剥離がある回転剥 離型, の 4 つの夕イプである.これらの 4 つのタイプの 代表的な流況の時間変動を図一1に示す. 図一1は，4 つのタイプの側面からみた流況の時間変化の概略を, 位 相を 8 分割して図示したもので, 眓中の番号は, 水位変 動に示される番号の位相であることを示す。たとえば, (1)の位相は, 波の谷の位相, (3)の位相は静水面を上向き に切る位相, (5)位相は波の峰の位相である. 以下に各 タイプの流況の時間変化の特徵の説明を行う.

a) 振動非剝離型（図一1 (a) 参照)

このタイプの流況は, 波一周期内で, 球表面を水粒子 が往復運動をする.しかし球背後での流線の剝離はない. 波の谷が通過する(1)の位相では, 波進行方向と逆向きの 水平方向流速が最大となり, 球表面の水粒子の動きも大 きい，しかし，流線は球表面に沿って流れ，球の後部に 集まり球から離れる. (2)の位相になると, 流速は小さく なり，球表面の水粒子の動きは小さくなる．波が静水面 を上向きに切る(3)の位相では, 水平方向流速がゼ口とな り, 球表面での水粒子の動きはほとんぎない. (4)の位相 では, 流速は逆転し, 水粒子は波進行方向に動き出し, 波の峰が通過する(5)の位相では, 波進行方向の流速が最 大となり, 水粒子の動きも大きくなるが, 剥離はなく, 流線は球表面に沿って流れる. (6)78(8)9位相では, (2) (3)(4)(5)の位相之同様の現象が対称な向きに繰り返され る. 


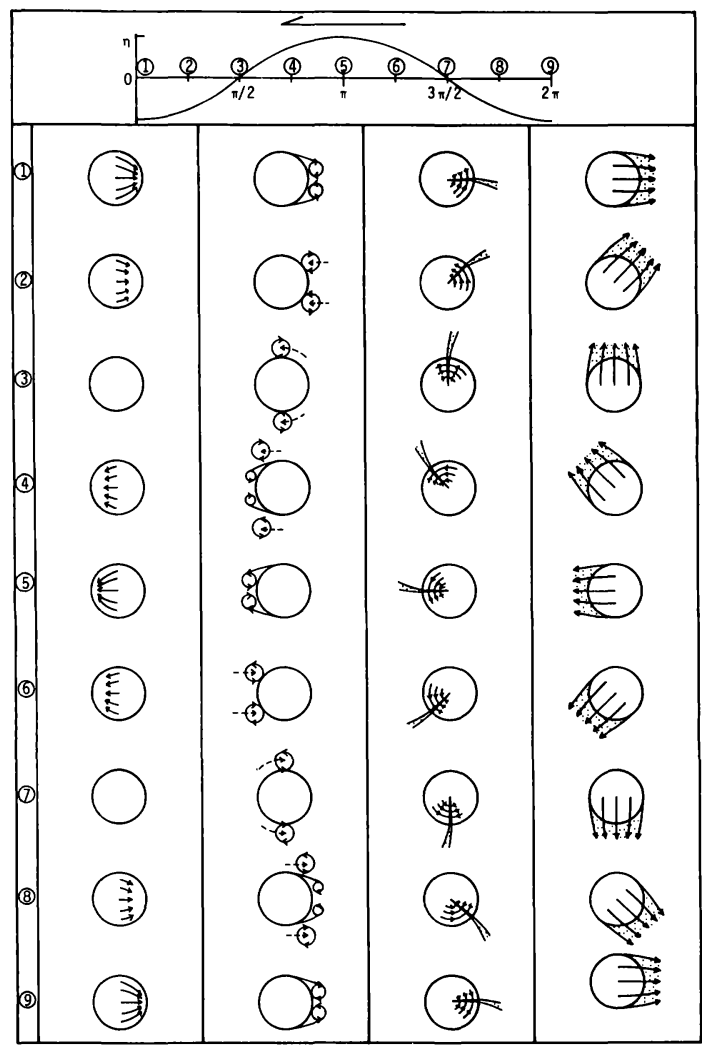

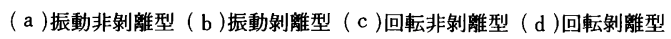

図一1 流況の時間変化の概念図

b）振動㓦離型（図一1 $(\mathrm{b})$ 参照）

このタイプの流況は, 往復運動が卓越することについ ては振動非剝離型と同じであるが，流線が剝離し，渦輪 が形成されることが大きな特徴である．波の谷が通過す る(1)の位相では, 球の背後に流線が激しく巻き込む.こ のとき, 先行した波で形成された渦輪が流されている. 流速が小さくなる(2)の位相では，流線の巻き込みは弱く なり，渦輪が大きく膨らみ，球の方へ引き付けられる. 波が静水面を上向きに切る(3)の位相では, 渦輪は球の真 上近くまで移動する．このとき球表面での水粒子の動き はほとんどない. (4)の位相では, 逆方向へ流線が巻き込 み始め,すでにできた渦輪は, 巻き込みの部分の外側へ 移動する．波の峰が通過する(5)の位相では，すでに形成 された渦輪は流されてしまう. また, 球の背後では, 流 線の巻き込みが激しくなり, 次の渦輪の形成が始まる. (6)(7)8(9)の位相では, (2)(3)(4)(5)同様な現象が対称な向 きに繰り返される.

c) 回転非剥離型 (図一1 (c) 参照)

このタイプは, (1)〜9)へ位相が進むに従い流れの方向 は変化するものの, 流況は波一周期にわたり安定してい る.この夕イプで特徴的なのは, 球表面で渦糸が形成さ

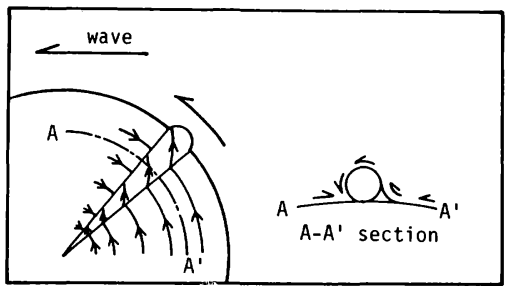

図一2 渦糸の概念図

れ，その渦糸が球表面を回転することである．渦糸は， 渦系の両側から渦系に向かう流線のうち, 前方からの流 線が後方からの流線にもぐり込むようにして形成され， 渦糸を形成する流線はらせん状になっている（図一2参 照)．らせんの進行方向は，球を側面からみた場合の円 の中心から外側へ向かっており, 最外縁で反対側から進 んできた渦糸と出会い，球から離れていく.

d) 回転剝離型 (図一1 $(\mathrm{d})$ 参照)

このタイプも(1) (9)への位相の進行に伴う波一周期内 での流況の時間変化は, 方向が変わるものの本質的な変 化はない，回転非剝離型とは異なり，球表面で渦系は形 成されず，球背後で流線の剝離が生じる，剝離域は，時 間とともに球表面を回転する。この場合，永離域は非常 に乱れており, 振動剝離型の場合のような渦輪の形成は 認められなかった。

この回転パターンと振動パターンの出現特性は, 実験 によると K.C. 数, $R e$ 数, $D / h$ による差異はほとん ゼなく, $h / g T^{2}, d / h$ に大きく支配される水粒子の楕 円軌道と関連があり，楕円軌道が偏平になると振動パ ターンが, 円軌道に近くなると回転パターンが出現する. 実験によれば下記のようになる.

$$
\begin{aligned}
& B / A>1 / 2 \cdots \cdots \cdot \text { 回転パターン } \\
& B / A<1 / 3 \cdots \cdots \cdot \text { 振動パターン }
\end{aligned}
$$

ここに, $A$ と $B$ はそれぞれ水粒子の楕円軌道の長軸と 短軸の長さであり, 本研究では, 微小振幅波理論によっ て計算した。しかし， $1 / 2$ から $1 / 3$ の間のケースは，必 ずしも回転パターン，振動パターンに分けられず両方の パターンが観測された。したがって， $1 / 3<B / A<1 / 2$ が回転パターン, 振動パターンの遷移領域である.

次に, 㓦離の有無について考察する. 剝離が生じると, 剝離域での圧力は低下し，そのため球の前後で圧力が非 対称になるため，抗力が大きくなる．慣性力は加速度に 比例する力であり，したがって，波高に比例した力であ る. また，渦の発生に伴う抗力は，流速の 2 乗に比例す る力であるため，波高の 2 乗に比例することになる．し たがって, 㔀離が始まると波高の増加に伴う波力の増加 の割合が急激に大きくなることになり，このことからも 永離の発生を支配するパラメーターを明らかにしておく ことが重要である. 図一 3 は, 剝離の有無と $K . C$. 数 


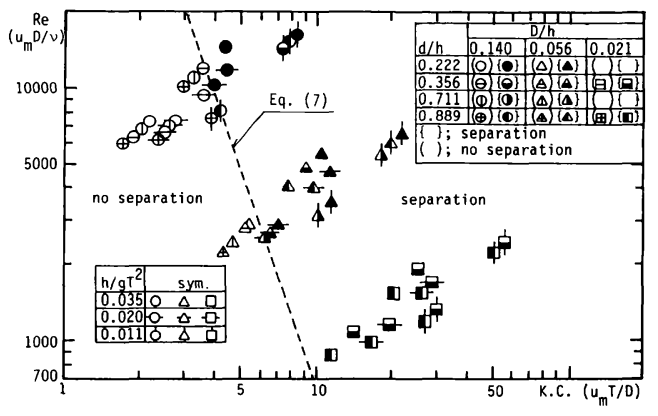

図一3 㔀離の支配パラメーター

$\left(u_{m} T / D\right), R e$ 数 $\left(u_{m} D / \nu\right)$ の関係を示したものであ る. 図中，黒塗の部分がある記号が剝離があることを示 し，黒塗の部分がない記号は剥離がないことを示す．同 図より，K.C. 数が大きくなると剥離が始まることがわ かるが, その $K . C$. 数の值は $R e$ 数によって若干変化 し, 本実験の範囲では, ほぼ図中の破線（式（7 )) で 与えることが可能である.

$$
R e=570000(\text { K.C. })^{-3}
$$

すなわち, $h / g T^{2}, d / h$ の值にかかわらず $K . C$. 数が $4 \sim 9$ 程度になると剥離は始まる。しかし, 剝離が始ま る $K . C$. 数の值は, $R e$ 数の小さい（粘性の影響が大き い）ところでは大きく，逆に $R e$ 数の大きい（粘性の影 響が小さい) ところでは小さくなっている．したがって 水の粘性の影響が大きいところでは剝離は起こりにく く, 小さいところでは剥離は起こりやすいことが指摘で きる。

\section{（2）球体に作用する波力の特性}

a) Morison 式の適用範囲

Morison 式は，本来直立円柱に作用する波力算定式 として提案されたため，本研究で対象とするような没水 球体に作用する波力算定式として適用できない場合があ ることが著者らによって明らかにされている ${ }^{6)} x$ 方向 波力については，波の谷が通過するとき，球の一部が自 由水面から出る場合を除いてすべてのケースに Morison 式は適用可能であった. $z$ 方向の波力に対する Morison 式の適用範囲を，本研究の実験值も加えて， $D / h$ をパラメーターにして図示すると図一4を得る. なお，Morison 式による計算波力と実測波力の相関係 数 $\gamma$ が 0.9 以下のときは Morison 式が適用できないも のと定義した ${ }^{6)}$. 図一4(a) には, 参考のため, $h / g T^{2}$ ごとに $B / A$ が $1 / 2$ 以下になる $d / h$ に対する実験値の 上限を結んだ曲線と， $B / A$ が $1 / 3$ 以下になる $d / h$ に対 する実験值の上限を結んだ曲線も記入してある．同図に よると, 鉛直方向波力に対する Morison 式の適用の下 限は, $B / A$ が $1 / 2$ 以下を示す曲線と $1 / 3$ 以下を示す曲 線の間にあることが認められる．実験 II で得られた振動

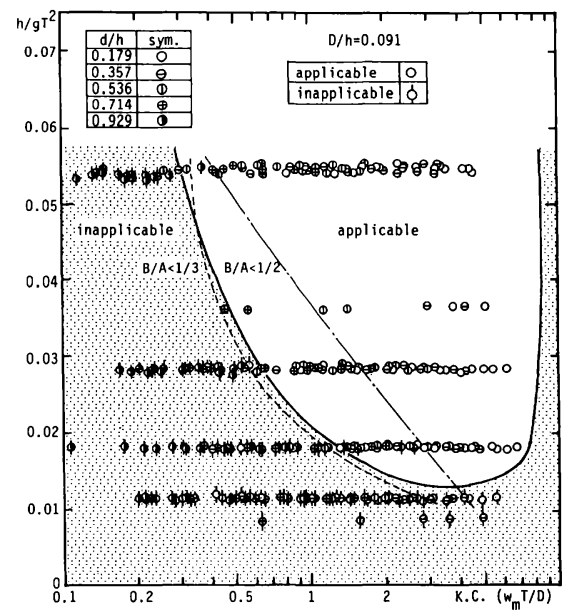

(a) $D / h=0.091$

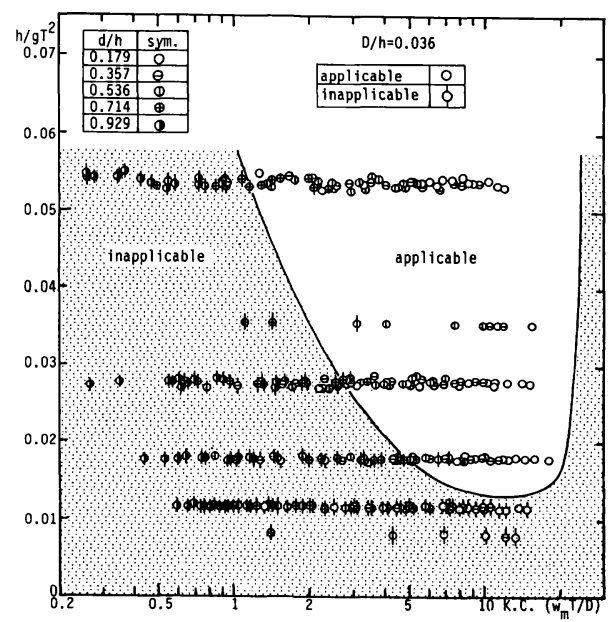

(b) $D / h=0.036$

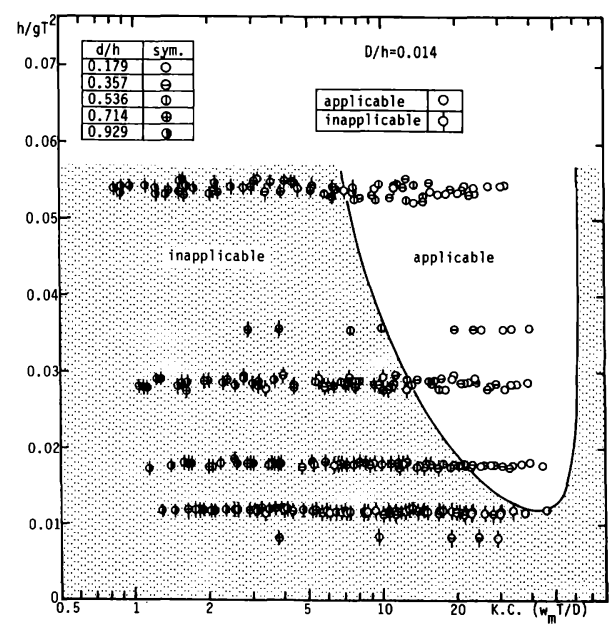

(c) $D / h=0.014$

図一4 Morison 式の適用範囲 ( $F_{z}$ の場合 $)$ 
パターンの波力のうち，鉛直方向波力は Morison 式で 算定できないものがほとんどであり，この結果も考慮す ると，流況のパターンが振動パターンになると Morison 式は適用できなくなるといえる。なお，本実験で対 象とした波は， $H / L<0.09, h / L>0.12$ (ここに，H は波高，Lは波長である) の波であり，いずれも砕波 していない波である。

Morison 式が適用できなくなる原因としては，揚力 の影響, Proximity Effect などが考えられる.振動パター ンでは，鉛直方向の水粒子の運動による抗力，慣性力が 水平方向の水粒子の運動による揚力に比べて小さくなる 可能性がある. 特に, $d / h$ が大きい底面付近のケース では，Proximity Effectにより，球の下側の流速が，上 側の流速に比べて大きくなることが，可視化実験からも 認められているが，この球の上下での流速の非対称性に より，鉛直方向に力が作用することになる．そのため Morison 式が適用できなくなったものと考えられる.

Morison 式の適用限界付近の $d / h$ の值では，同じ $d / h$ の值であっても，K.C. 数が大きくなれば Morison 式が適用できる傾向があることが認められる.

$K . C$. 数が大きくなることは，鉛直方向の運動が大きく なることに対応するが，鉛直方向の運動が大きくなると 鉛直方向の抗力, 慣性力も大きくなり，そのためMorison 式は適用できるようになったものと思われる.また， $D / h$ が 0.014 の場合は Morison 式を適用できなくなる $d / h$ の值は大きくなることが認められる。これは，本 研究では, $D / h$ が小さいことは球の直径が小さいこと に対応し，したがって，球に作用する力の絶対值が球の 直径が大きい場合に比べて小さくなり，そのため $D / h$ が小さい 0.014 の場合は, Morison 式が適用できる範 用が狭くなったものと考えられる。

上記の結果は， $x$ 方向之 $z$ 方向とでは，揚力の影響 の大きさに差があることを示すものでもあり，したがっ て，球体に作用する波力を Morison 式で算定する場合 には，Morison 式の適用範囲内の波力であっても，波 力係数は, $x$ 方向と $z$ 方向とで独立させて考える必要 性があることを示している.

b）慣性力係数の特性

図一 5 に $x$ 方向の慣性力係数 $C_{M x}$ と K.C. 数 $\left(u_{m} T / D\right)$ の関係を示す. $K . C$. 数が 10 以下の範囲で は, $h / g T^{2}, d / h, D / h$ の值に関係なく, $C_{M x}$ は K. C. 数の増加に伴い若干増加する傾向は認められる が，概略は一定値をとるとみなし得る. K.C. 数が 10 ～30 を越えると， $C_{M x}$ の值に差が生じる．あまり顕著 ではないけれども， $d / h$ が 0.539 より大きいものはほ ぼ一定値をとるが， $d / h$ がそれより小さいものは， K. C. 数の増加に伴い減少し, K.C. 数が 20 前後で極
小值をとる. $K . C$. 数が, 30 を越えると, $C_{M x}$ は徐々 に大きくなり，50 以上の範囲では急激に増加する. K.C. 数が 5 20 の範囲では，振動流中におかれた球体 に対する Sarpkaya ${ }^{13)}$ ，中村ら ${ }^{14)}$ の実験值とほぼ等しい 值になっている. また，K.C. 数が 20 前後で $C_{M x}$ が極 小值をとる傾向も著者らの結果 ${ }^{6)}$ 之一致する. しかし, 著者らの $C_{M x}$ の極小值の結果 $\left.{ }^{6}\right)$ は，本研究に比べてかな り小さい，著者らの結果 ${ }^{6)}$ で，特に $C_{M x}$ の極小値が小さ い值は，ほとんどが $d / h$ が 0.15 以下の值であり，本実 験の $d / h$ の最小值よりも小さい。したがって，これは， $d / h$ の実験範囲の差によるものと考えられる.

$K . C$. 数が， 10 以上の範囲で $C_{M x}$ の特性が変化する のは，以下のような理由によるものと考えられる. K.C. 数が 10 を越えると後述するように, 流況パター ンにかかわらず，抗力が卓越するようになる，これは， 球体背後の剥離域が大きくなり，剝離域の圧力低下によ る球前後の圧力の非対称性が顕著になるためである．剝 離域での圧力の低下が顕著になると，球表面での圧力分 布が，剝離がない場合に比べて大きく変化することにな り,その影響が慣性力係数に現われたものと考えられる. 特に， K. C. 数が 30 を越えるとその影響が非常に大き くなるものと推察される.なお, 本論では図示しないが, $R e$ 数による $C_{M x}$ の有意な差異は認められなかった。

次に, $z$ 方向の慣性力係数 $C_{m z}$ と $K . C$. 数 $\left(w_{m} T / D\right)$

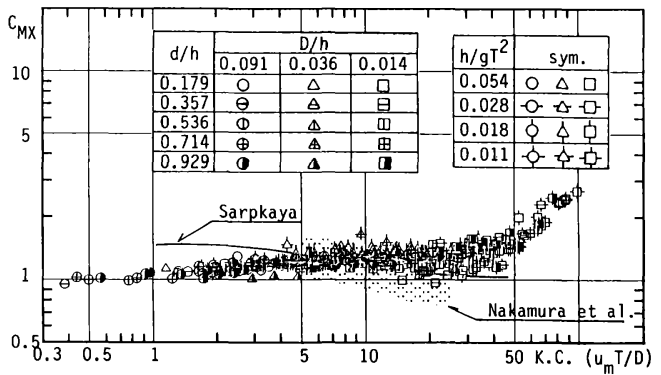

図一5 $C_{M x}$ と K.C. 数の関係

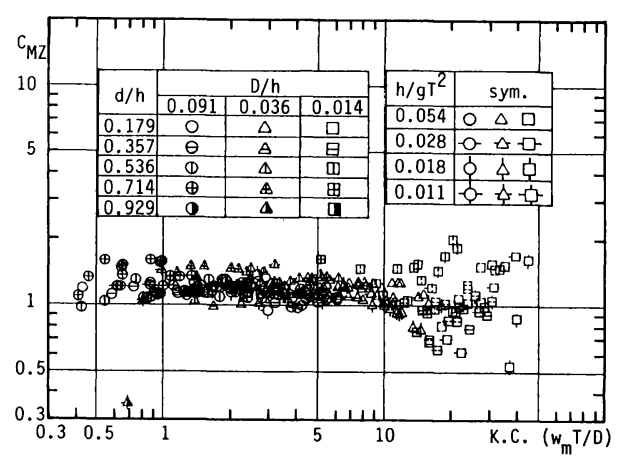

图一6 $C_{m z}$ と K. C. 数の関係 
の関係を図一6に示す. $C_{M z}$ は, $K . C$. 数が 10 以下の 範囲では，ほぼ一定值をとるが，10 以上では，K.C. 数の増加に伴い減少し, K.C. 数が 20 前後で極小值を とり, その後 $K . C$. 数の増加に伴い $C_{M z}$ は増加する. $C_{M x}$ とは異なり, K. C. 数が 30 を越える值が少ないた

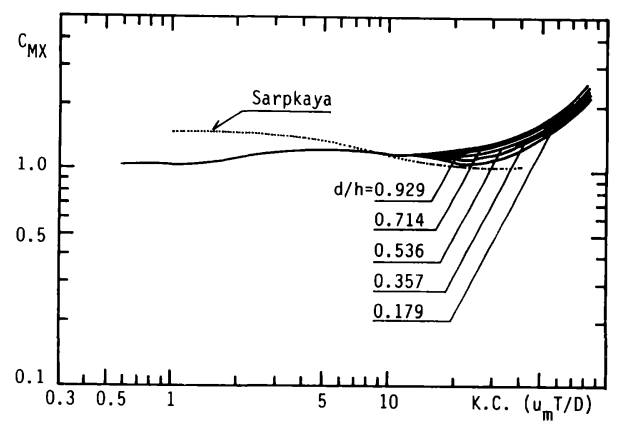

図一 $C_{M x}$ と $K . C$. 数の関係（実験曲線）

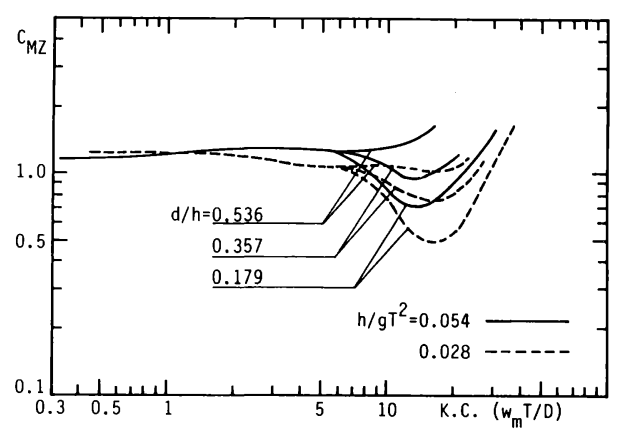

図-8 $C_{M z}$ と $K . C$. 数の関係（実験曲線）
め, 30 以上の範囲については, $x$ 方向と比較すること はできないが, それ以下の範囲では， $C_{M z}$ の方が多少ば らつきが大きいものの, 基本的には, $C_{M x}$ とよく似た傾 向であるといえる. K. C. 数が 20 前後で $C_{M z}$ が極小值 をとり, その值が $d / h$ が小さいほど小さくなる傾向は $C_{M x}$ の場合亡同様であるが, $d / h$ のほかに, $h / g T^{2}$ が 小さい方が極小值はより小さくなるようである.さらに, その極小值は $C_{M x}$ に対する值より小さく, $C_{M z}$ は $C_{M x}$ よりも慣性力係数の変化が大きいといえる.これらの差 の原因の 1 つに $C_{M x}$ と $C_{M z}$ に含まれる揚力の大きさが 異なることが挙げられる.

図一5，6に示される慣性力係数の平均的な值はそれ ぞれ図一7，8で与えることができる.したがって，こ れらの図に示される值を使えば，実験值には若干の分布 の幅はあるものの, 与えられた条件に対する慣性力係数 の妥当な值を得ることができる，ただし， $C_{M z}$ について は, $d / h$ が0.714より大きい場合, あるいは, $h / g T^{2}$ が 0.011 の場合のほとんどが Morison 式を適用できな いため実験值が少ない. また, $h / g T^{2}$ が 0.018 の場合 の実験值も少なく,$d / h$ による明暸な傾向が認められ なかったため, 図一8には, $h / g T^{2}$ が 0.028 以上, $d / h$ が 0.536 以下の実験值に対する曲線のみを示した. なお，慣性力が卓越すると考えられる $K . C$. 数が 10 以 下の範囲（4. ( 3 ）のd) 参照) での実験曲線に対する 実験値の標準偏差は, 最大で 0.1 程度である.

c) 抗力係数の特性

図-9に $x$ 方向の抗力係数 $C_{D x}$ と $K . C$. 数 $\left(u_{m} T / D\right)$ の関係を示す. ただし, $K . C$. 数が 5 以下の $C_{D x}$ の值は, 非常にばらつきが大きいこと, また,この範囲の波力は, 慣性力が支配的であり，

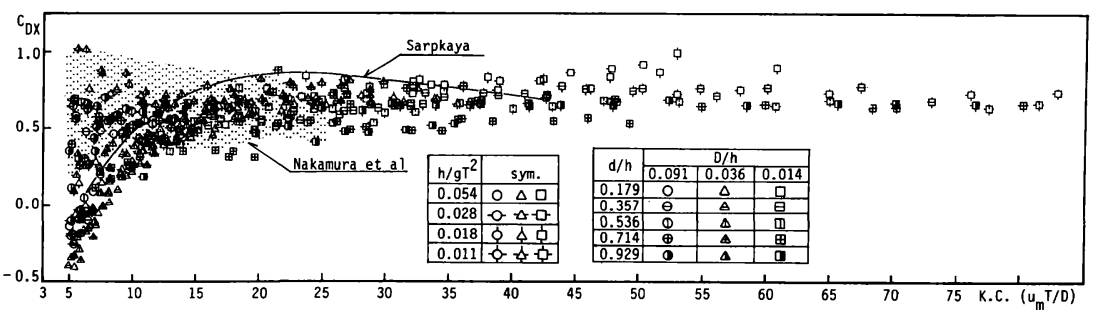
作用波力を慣性力のみで ほぼ表現できるため，こ こでは, K.C. 数が 5 以 上の範囲のみを示した。 全体的な傾向としては, $C_{D x}$ は, K.C. 数が 10 以 上では一定值に近づき, 図一9 $C_{D x}$ と K.C. 数の関係 $h / g T^{2}, d / h, D / h$ の 値による差はほとんど

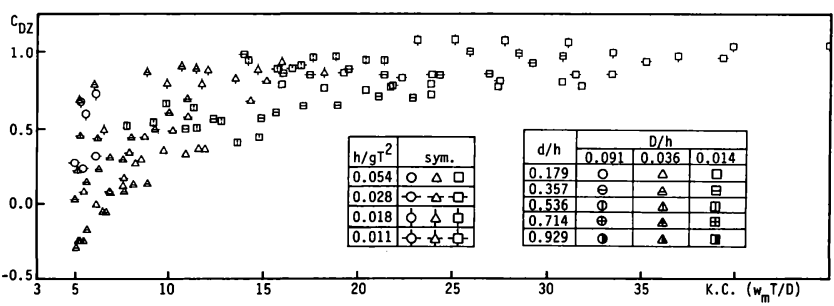

図一10 $C_{D z}$ と K.C. 数の関係 ないようである，K.C. 数がそれ以下では, $C_{D x}$ の值にかなりの幅がでる. その差は, $K . C$. 数が小さいほよ゙大きい. $K . C$. 数が 10 以上では, 前述したように, 流況のパター ンにかかわらず後流域が発達し，そのため, 球の前後での圧力差がかなり大きくなり，そ れによる力が抗力の支配的な力となる.その ような状況のもとでは, $h / g T^{2}, d / h$ のよ 


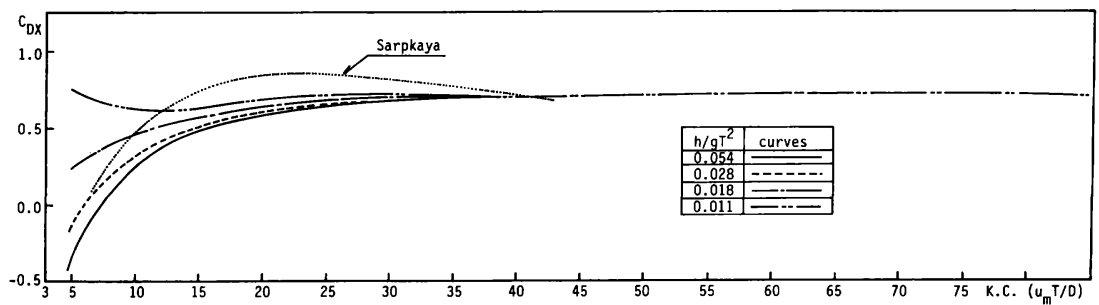

図一11 $C_{D x}$ と K.C. 数の関係（実験曲線）
の割合が顕著になるよう である、これは, 同じ K.C. 数と $h / g T^{2}$ に対 して, $D / h$ が小さいこ とは, $R e$ 数が小さいこ とになり，したがって， 粘性の影響がより大きく なるためであると考えら れる。

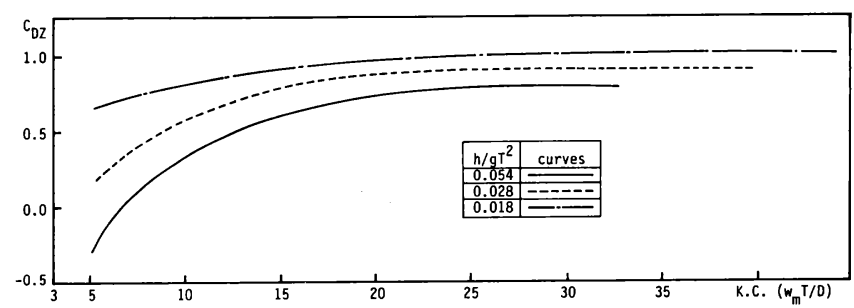

図一12 $C_{D z}$ と $K . C$. 数の関係（実験曲線）

うな流況を支配するパラメーター，言い換えれば，回転 パターン，振動パターンによる差はほとんよ゙ないといえ る. 一方, $C_{D x}$ の值に大きな差が認められる $K . C$. 数 が 10 以下の範囲では, $h / g T^{2}$ の大きい方が同じ $K . C$. 数の值であっても $C_{D x}$ の值は小さく, $h / g T^{2}$ の小さい 方が $C_{D x}$ の值は大きくなる．また， $h / g T^{2}$ の差ほど明 瞭ではないが, $d / h$ が大きいほど $C_{D x}$ の值は大きくな るようである.すなわち, $h / g T^{2}$ が小さく, $d / h$ が大 きい場合は, $K . C$. 数の減少に伴い $C_{D x}$ の值はどちら かというと大きくなる傾向にあり, $h / g T^{2}$ が大きく, $d / h$ が小さい場合は $C_{D x}$ は減少する傾向にあることが わかる. $h / g T^{2}$ と $d / h$ は流況のパターンを支配する無 次元量でもあるので, $K . C$. 数が小さい範囲では, 流況 のパターンによって $C_{D x}$ の值は大きく変化することを 示すものである. $K . C$. 数が小さい範囲では, 球表面で の流れの剝離はあまり顕著でなく, したがって, 抗力に 占める球表面での粘性抵抗力が大きくなることが考えら れる. 粘性抵抗力は, 球表面での流速分布に大きく支配 されるため, 回転パターンと振動パターンでは, 粘性抵 抗力に差が生じることになる. $h / g T^{2}, d / h, D / h$ が 同じ值ならば, $K . C$. 数が小さくなれば, $R e$ 数も小さ くなり,したがって, 㔀離の影響が小さくなると同時に 粘性の影響が大きくなる．このため，K.C. 数が小さく なると $C_{D x}$ により大きな差が生じるものと考えられる. また， $h / g T^{2}$ が同じであっても，D/hにより $C_{D x}$ の值 に差があることが認められる．すなわち， $h / g T^{2}$ が 0.018 より大きい場合は, $D / h$ の小さい方が $K . C$. 数 の減少に伴う $C_{D x}$ の減少の割合が顕著であり, $h / g T^{2}$ が 0.011 の場合は, $K . C$. 数の減少に伴う $C_{D x}$ の増加
次に, $C_{D z}$ と $K . C$. 数 $\left(w_{m} T / D\right)$ の関係 を図一10に示す. Morison 式が使えない波 力に対する值を除いているため $C_{D z}$ の実験 值が少ないが，一般的には $C_{D x}$ とよく似た 傾向を示している.

図一9, 図一10に示される抗力係数の值を 慣性力係数の場合と同様に, その平均的な值 を使って示すとそれぞれ図一11，図一12の ようになる. 抗力係数は， $K . C$. 数が 10 以 下の範囲では, $d / h$ と $D / h$ によっても多少差があるが, $h / g T^{2}$ による差異ほよ゙は明瞭でないため,ここでは $h / g T^{2}$ の值をパラメーターとして表示した. なお，抗 力が卓越すると考えられる $K . C$. 数が 10 以上の範囲 (4. ( 3 ）のd) 参照) での実験曲線に対する実験値の 標準偏差は，最大で 0.11 である.したがって， Morison 式の適用可能な範囲の波力については，図一7, 8，11，12に示される波力係数を使用することにより， 波力を推算することができる.

d）最大波力の特性

$x$ 方向の無次元最大波力 $F_{x m} / \rho\left(u \sqrt{u^{2}+w^{2}}\right)_{m} D^{2}$ 亡 $K . C$. 数 $\left(u_{m} T / D\right)$ の関係を図一13に示す. 次元解析 によれば, 無次元最大波力は, $x$ 方向については, $F_{x m} / \rho u_{m}^{2} D^{2}, z$ 方向については, $F_{z m} / \rho w_{m}^{2} D^{2}$ で表現す るのが本来の表示法であるが, Morison 式の抗力項と の関連を考慮して, $x$ 方向については, $F_{x m} / \rho\left(u \sqrt{u^{2}+w^{2}}\right)_{m} D^{2}$, また, $z$ 方向については, $F_{z m} / \rho\left(w \sqrt{u^{2}+w^{2}}\right)_{m} D^{2}$ で表示する. なお， $x$ 方向につい ては, $F_{x m} / \rho\left(u \sqrt{u^{2}+w^{2}}\right)_{m} D^{2}$ と $F_{x m} / \rho u_{m}^{2} D^{2}$ は同じ值で ある、また，図一13には，式（7）で計算される剥離 が始まる $K . C$. 数の值について, 本実験の範囲におけ る最小値と最大值を一点鎖線で示した. 同図より, 無次 元最大波力は, 剝離のない K. C. 数が 4 以下では, $K . C$. 数の-1乗に比例して減少し, 㔀離が始まる K.C. 数が 4 あたりから減少の傾きが若干緩やかにな る. また, K.C. 数が 10 を越え, すべてのケースで剝 離が起こるようになると無次元最大波力は一定值に漸近 してゆき，20 以上では，ほぼ一定值になる傾向が認め られる. 無次元最大波力が $K . C$. 数の-1 乗に比例する 
範囲では, 波力の最大值は, 流速に比例することになる。 すなわち，慣性力が支配的であったことが考えられる. また, K.C. 数の変化によらず一定值をとる範囲では, 波力の最大値は, 流速の 2 乗に比例することになり, 抗 力が支配的であったと考えられる. 実験 IIによって得ら れた波力について同様の整理を行った結果, 実験 II の無 次元最大波力と $K . C$. 数の関係は図一13に示されるも のとまったく同じであり，さらに，剥離が始まる $K . C$. 数が 4 付近加ら K.C. 数の増加に伴う無次元最大波力 の減少の傾きが緩やかになり, さらに, 無次元最大波力 が一定値となる範囲では，すべて剝離のある值であるこ とがわかった5).これらの結果より, 㓦離のない範囲で は, 波力の最大值は流速, すなわち波高に比例し, 剝離 が起こり始めると波力の最大值は徐々に増加し, 剥離が 顕著に起こるようになると流速の 2 乗, すなわち波高の 2 乗に比例するといえる.したがって, 波力の最大值は, 㔀離の有無に大きく支配されている.

図一13には，Morison 式中の慣性力，抗力に対する 值もそれぞれ実線, 破線で記入してある. ただし, 慣性 力係数の值は, 図一7より慣性力が支配的である $K . C$. 数が 10 以下の範囲の平均値 1.2 を，また，抗力係数の 值は, 図一11 より抗力が支配的である $K . C$. 数が 10 以 上の範囲の平均値 0.7 を採用した. 図中の実線, 破線は, それぞれ, K.C. 数が 10 以下, 10 以上で実験値との対 応が非常によいことがわかる. したがって, 波力の最大 值の推算は, 図一7, 11 の波力係数を使って行うことが できる.

$z$ 方向の無次元最大波力 $F_{z m} / \rho\left(w \sqrt{u^{2}+w^{2}}\right)_{m} D^{2}$ 之 K.C. 数 $\left(w_{m} T / D\right)$ の関係を図一14に示す.ただし, Morison 式が適用できない波力の值は除いてある. $z$ 方 向の無次元最大波力の特性は, $x$ 方向の值に比べて多少 ばらつきが大きいもののその基本的な特性は，ほとんど 差はないといえる. $z$ 方向の值が $x$ 方向の值に比べて ばらつきが大きい原因の 1 つとして，揚力の影響が考え られる. 同図にも図一8, 12 から得られる波力係数を使っ て計算される慣性力, 抗力の值も示してある. ただし, $C_{M z}$ の値は, 慣性力が卓越する $K . C$. 数が 10 以下の範 囲では $h / g T^{2}$ による差は小さいため, $h / g T^{2}$ が 0.054 , 0.028 ともに 1.3 として計算し, $C_{D z}$ の值は, 抗力が支 配的な K.C. 数が 10 以上の範囲の平均值として, $h / g T^{2}$ が 0.054 に対しては $0.7,0.028$ に対しては $0.85,0.018$ に対しては 1.0 として計算した。 また， $z$ 方向の慣性力については $h / g T^{2}, d / h$ によって計算值 が変化するため, Morison 式の適用範囲内の最大值 $\left(h / g T^{2}=0.054, d / h=0.179\right)$ 之最小值 $\left(h / g T^{2}=\right.$ $0.028, d / h=0.536)$ を示した. 実験值と計算値の対応 は非常によく, 同図からも図一8，12 の波力係数の值が

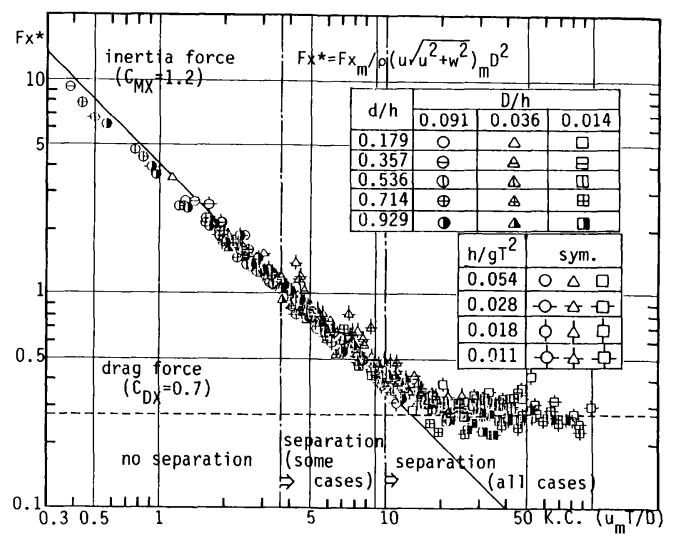

图-13 $\quad F_{x m} / \rho\left(u \sqrt{u^{2}+w^{2}}\right)_{m} D^{2}$ とK.C. 数の関係

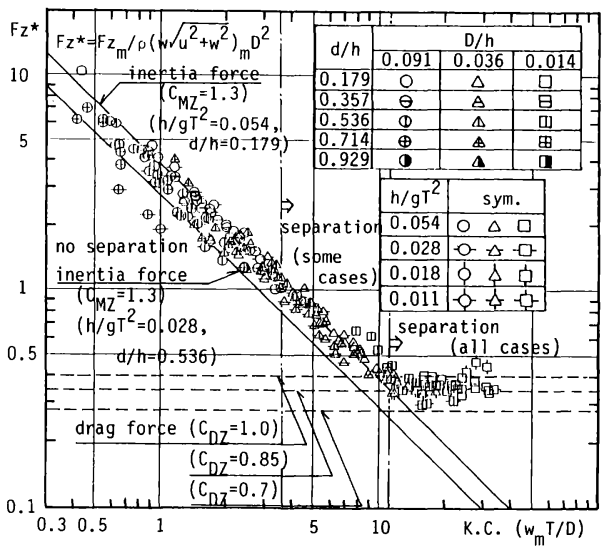

图一14 $F_{z m} / \rho\left(w \sqrt{u^{2}+w^{2}}\right)_{m} D^{2}$ とK.C. 数の関係

妥当であることが認められる.

\section{5. 結言}

以上，水理実験に基づき没水球体に作用する波力の特 性を, 球体周りの流況亡関連づけて検討を加えてきた.

本論で得られた結果を以下に要約する.

（1）球体周りの流況は, 振動非剝離型, 振動剥離型, 回転非剝離型, 回転剝離型, の 4 つのタイプに大別され る.

（2）流況のパターンは， $h / g T^{2}$ と $d / h$ に大きく支 配される． $h / g T^{2}$ が小さく, また， $d / h$ が大きくなり， 水粒子の楕円軌道の短軸と長軸の比が $1 / 3$ 以下になると 振動パターンが現われ，逆に， $h / g T^{2}$ が大きく，また， $d / h$ が小さくなり短軸と長軸の比が $1 / 2$ 以上になると 回転パターンが現われる (式 $(6)$ 参照).

（3）流線の剥離は，K．C. 数が 4 9 で始まる．粘 性の影響が大きいほど剥離は起こりにくく, 剥離が始ま る K.C. 数の值は, $R e$ 数によって変化する. $R e$ 数が 小さいときは剝離が始まる $K . C$. 数の值は大きく, 逆 
に, $R e$ 数が大きいときは小さくなり, その限界の值は, 式（7）で与えられる.

（4）振動パターンでは，水平方向の水粒子の運動が 卓越するため, 鉛直方向に作用する揚力が大きくなる. そのため, 鉛直方向波力の算定に Morison 式を使うこ とができない.

（5）抗力係数は，K.C. 数が 10 以上になり㔀離が 顕著に起こるようになると, 流況のパターンにかかわら ずほぼ一定值になる. しかし, K. C. 数が 10 以下の範 囲では, 流況のパターンによって值は変化し, $h / g T^{2}$ が大きいほよ゙，また， $d / h$ が小さいほど抗力係数は小 さくなる.

（6）慣性力係数は, 剝離が余り顕著でないK.C. 数が 10 以下の範囲では, 流況のパターンと関係なくほ ぼ一定値となる. しかし, 㔀離が顕著になると, 慣性力 係数は, K.C. 数の増加に伴い減少し, K.C. 数が 20 前後で極小值をとり, その後, $K . C$. 数の増加に伴い増 加する. 慣性力係数の極小值は, $d / h$ が小さいほど小 さく，また， $C_{M x}$ より， $C_{M z}$ の方が小さい.

（7）慣性力係数の平均的な值は, 図一7, 図一8に, また, 抗力係数の平均的な値は, 図一11, 図一12にそ れぞれ示される曲線で与えられる.

（８）波力の最大值は, 流線の剝離により大きく支配 され, 剝離がない場合は, 波力の最大值は波高に比例す るが, K.C. 数が 10 以上になり, 剝離が顕著になると 波力の最大值は波高の 2 乗に比例する.

今後, 球体に作用する揚力の特性, Proximity Effect の影響を定量的に評価し，Morison 式が適用できない 範囲の波力の算定式を確立する必要がある. 最後に, 本 研究を行うにあたって, 実験, 解析に多大な協力をいた だいた川角伸彦君（現・日本電信電話株式会社）に謝意 を表する次第である.

1）たとえば, Chakrabarti, S.K. : In-line forces on fixed vertical cylinder in waves, J. Waterway, Port, Coastal and Ocean Div., Proc. ASCE, Vol. 106, No. WW 2, pp. $140 \sim 155,1980$.

2）河野二夫：球状構造物の波による鉛直方向の流体力一重 複波一, 琉球大学理工学部紀要 (工学編), pp. 37 46, 1974.

3) Jenkins, S. A. and Inman, D. L. : Forces on a sphere under linear progressive waves, Proc. 15 th Coastal Eng. Conf., ASCE, pp. 2413 2428, 1976.

4) Iwata, K., Mizutani, N. and Kasai, S. : Irregular wave forces acting on a submerged sphere, Coastal Eng. Japan, Vol. 30, No. 1, pp.117 130, 1987.

5）岩田好一朗・水谷法美・川角伸彦：波動場におかれた没 水球体近傍の流れの特性と波力に関する研究, 第 35 回海 岸工学講演会論文集, pp. 612 616, 1988.

6）岩田好一朗・水谷法美・川角伸彦：没水球体に作用する 波力の特性に関する実験的研究一Morison 式の適用限界 について一, 第 34 回海岸工学講演会論文集, pp. 601 605, 1987.

7) Grace, R.A. and Cassiano, F. M. : Ocean wave force on a subsurface sphere, J. Waterways and Harbors Div. , Proc. ASCE, Vol. 95, No. WW 3, pp. 291 317, 1969.

8) Morison, J.R., O'Brien, M. P., Johnson, J. W. and Schaaf, S.A. : The wave force exerted by surface wave on piles, Petroleum Trans., AIME, Vol.189, pp. 149 157, 1950.

9) Keulegan, G. M. and Carpenter, L.H. : Forces on cylinders and plates in an oscillating fluid, J. Res. Nat. Bur. Stand., Vol.60, No. 5, pp.423 440, May, 1958.

10）上北征男 ・ 山崎秀勝：水平円柱に関する質量力に関する 研究, 第 27 回海岸工学講演会論文集, pp. 358 362, 1980.

11）中村廣昭 - 池田駿介 - 大八木崇：正弦振動流中におかれ た球に作用する流体力 (続報), 第 30 回海岸工学講演会 論文集, pp. 381 384, 1983.

12) Kohama, Y. and Kobayashi, R. : Boundary-layer transition and the behaviour of spiral vortices on rotating sphere, J. Fluid Mech., Vol. 137, pp. 153 164, 1983.

13) Sarpkaya, T. : Forces on cylinders and sphere in a sinusoidal oscillating fluid, J. Appl. Mech., Trans. ASME, Vol. 42, pp. 32 37, 1975.

14）中村廣昭 - 池田駿介 - 高柳 聡 : 正弦振動流中に置かれ た球に作用する流体力, 第 29 回海岸工学講演会論文集, pp. 443 446, 1982.

(1988.7.1 - 受付) 